\title{
Memanfaatkan Teknologi Media Sosial Instagram pada Kegiatan Pembelajaran dengan Menggunakan Metode Poster in Instagram (Postingan Terbaik)
}

\author{
Sano Hidayat ${ }^{a, 1^{*}}$, Yogi Nugraha ${ }^{\text {b, } 2}$, Yudi Firmansyah ${ }^{c, 3}$ \\ a Pendidikan Pancasila dan Kewarganegaraan, Universitas Buana Perjuangan Karawang, Indonesia \\ 1 pk16.sanohidayat@mhs.ubpkarawang.ac.id \\ *korespondensi penulis
}

\section{ABSTRAK}

Penelitian ini bertujuan untuk mendeskripsikan manfaat teknologi media sosial instagram sebagai dari proses pembelajaran dalam menggunakan metode pembelajaran poster in instgaram (postingan terbaik). Pada siswa kelas X-IPA 5 SMA Negeri 1 Klari, proses pembelajaran dengan menggunakan metode pembelajaran poster in instagram (postingan terbaik) pada mata pelajaran PPKn materi Nilai-nilai Pancasila. Penelitian ini menggunakan pendekatan kualitatif metode deskrptif. Subjek dalam penelitian ini merupakan siswa kelas XIPA 5 dan Guru pengampu mata pelajaran PPKn SMA Negeri 1 Klari, pengambilan sample menggunakan teknik purposive sampling pada siswa kelas X-IPA 5 yaitu dua orang siswa dan dua orang siswi. Hasil dari penelitian ini siswa diajak untuk memposting hal positif atau bijaksana di instagram dan sebagai publikasi dari prolehan hasil karya.

\section{ABSTRACT}

This study aims to describe the benefits of Instagram social media technology as a part of the learning process using the "poster in instgaram" learning method (best post). In class X-IPA 5 SMA Negeri 1 Klari, the learning process uses the poster in Instagram learning method (the best post) in the PPKn subject, the Pancasila Values material. This research uses a qualitative descriptive method. Subjects in this study were students of class XIPA 5 and teachers of PPKn subjects at SMA Negeri 1 Klari. Samples were taken using purposive sampling technique in class $X$-IPA 5 students, namely two male students and two female students. The results of this study were invited students to post positive and wise things on Instagram and as a publication of the results of their work.
Informasi Artikel

Diterima: 11 Januari 2021

Disetujui: 20 Februari 2021

Kata kunci:

Teknologi pembelajaran media social Instagram

Pembelajaran poster in instagram
Article's Information:

Received: 11 January 2021

Accepted: 20 February 2021

Keywords:

Learning technology

Instagram

Method learning poster in

Instagram.

\section{Pendahuluan}

Penggabungan dari aktivitas kegiatan manusia dengan teknologi hari ini sangat perlu untuk dijadikan sebagai kegiatan positif yang terarah dalam menciptakan teknologi sebagai alat atau media untuk dapat memudahkan kegitaan manusia. Teknologi banyak dapat dirasakan oleh manusia dalam memberikan pengalaman dan kemudahan yang sangat berbeda dari masa ke masa. Menunjukan perkembangan ini terus berjalan, perkembangan yang terus berkembang sehingga menghasilkan kemudahan untuk umat manusia terhadap permasalahan-permasalahan yang terjadi dalam kehidupan manusia sehingga permasalahan tersebut dapat diatasi semaksimalnya, oleh kecanggihan teknologi era industri 4.0. Dalam hal ini alfa (2018) menjelaskan pada dasarnya mesin beroperasi secara independen atau berkoordinasi dengan manusia (Alfa, 2018).

Terlihat ketika hari ini manusia tidak bisa lepas dengan teknologi telpon genggam. Negara Indonesia yang jumlah penduduknya banyak, tidak dapat di pungkiri maka Negara Indonesia akan menjadi sebagai penggiat dari berbagai macam teknologi sebagai alat untuk membantu proses aktivitas hidup manusia. Hal yang menjadi sorotan utama salah satunya dalam bidang pendidikan, 
dimana aktivitas pembelajaran di era revolusi industri 4.0 memanfaatkan teknologi sebagai media pembelajaran.

Perubahan-perubahan tak terduga menjadi fenomena yang sering muncul pada era revolusi indutsri 4.0. Dimana banyak aktivitas dilakukan melalui teknologi, media sosial yang menjadi sebuah komoditas banyak digunankan oleh masyarakat dunia saat ini, bahkan Indonesia sendiri pengguna aktif dari media sosial. Berkaitan kepada pemaparan Agustinus T (2018) bahwa perkembangan teknologi dan informasi dalam bentuk media sosial pada saat ini sangat berdampak bagi kehidupan manusia (Tampubolon, 2018). Dampak negatif yang ditimbulkan dari perkembangan media sosial selain merosotnya nilai-nilai karakter yaitu penyebaran berita bohong, pembullyan, terror, dan lainnya. Berbagai macam ancaman yang di timbulkan dalam teknologi dan informasi media sosial, kekhawatiran terhadap siswa dalam menggunakan teknologi media sosial dimana dengan media sosial dari satu smartphone saja siswa dapat memiliki beberapa akun media sosial diantaranya akun facebook, twitter, instagram dan lain-lain. Merujuk kepada penjelasan Ibda (2018) bahwa perkembangan di abad 21 terjadi kemajuan teknologi bergerak pesat, negara memerlukan Sumber Daya Manusia (SDM) yang memiliki tiga pilar penting yaitu literasi, kompetensi, dan karakter (Ibda, 2018).

Perkembangan sistem dalam dunia pendidikan dengan adanya sebuah kecanggihan teknologi yang tidak dapat untuk kita batasi. Bukan merupakan sebuah masalah yang berat namun ini harus jadikan sebagai dari persiapan kita untuk dapat menyesuaikan dengan baik dan menjadikan kecanggihan ini sebagai dari kemudahan. Banyak guru-guru yang sudah beralih untuk mengembangkan teknologi sebagai dari untuk dijadikan media pembelajaran ataupun sebagai metode pembelajaran yang berpusat pada pengasaan teknologi dan aktivitas melalui teknologi yang sebagaimana dalam menggunakan teknologi tersebut dengan baik.

Dalam hal ini media pembelajaran yang memanfaatkan media sosial sudah banyak digunakan sesuai dengan Kind T. \& Evans $Y$ yang menjelaskan tentang salah satu alternatif solusi yang bisa dikembangkan adalah pemanfaatan media sosial sebagai media pembelajaran. Media sosial dipilih karena merupakan trend yang sedang berkembang saat ini (dalam Irwandani, 2016). Terkhusus media sosial instagram menjadi media sosial terbanyak yang digunakan oleh masyarakata dunia bahkan masyarakat Indonesia aktif dalam menggunakan media sosial instagram terbanyak. Dengan memanfaatkan media sosial ini sebagai dari kegitan pembelajaran untuk terciptanya kebiasaan siswa dalam menggunakan media sosial dengan baik dan bijak. Media pembelajaran dari metode pembelajaran poster in instagram (postingan terbaik) merupakan sebuah media pemebalajaran baru yang dibantu dengan teknologi smartphone. Penggunaan smartphone sudah banyak di gunakan oleh kalangan siswa menengah atas bahkan siswa sekolah menengah pertama. Tidak di pungkiri dalam menggunakan metode ini, hal yang paling penting yaitu jaringan internet yang terkoneksi dengan baik untuk menunjang proses pembelajaran agar berjalan dengan lancar.

Metode pembelajaran poster in instagram (postingan terbaik) para peserta didik diajak untuk membangun nilai-nilai karakter kreatif dan bertanggung jawab menjadi tujuan utama yang diharapkan oleh metode pembelajaran ini, melalui pembiasaan untuk memposting sesuatu hal yang positif diakun Instagram masing-masing. Nugraha \& Rahmatiani (2018) menjelaskan bahwa. Manusia-manusia terdidik ini tidaklah cukup hanya dengan bermodalkan IQ tinggi dan pengetahuan yang luas, akan tetapi diperlukan sebuah keterampilan berperilaku baik dalam setiap langkahnya" (Nugraha \& Rahmatiani, 2018). Selain dari pengetahuan yang luas tentunya kita tidak harus untuk 
fokus kepada pencapaian IQ tinggi tanpa menanamkan keterampilan berprilaku baik, sebaiknya dapat kita lakukan pengetahuan itu dengan keterampilan berprilaku baik secara seimbang.

Agustinus menjelaskan melalui media sosial instagram, diharapkan nilai - nilai karakter dapat ditanamkan dan dibiasakan sehingga menjadi budaya bersosialisasi diera globalisasi (Tampubolon, 2018). Metode pembelajaran poster in instagram (postingan terbaik) sangat cocok untuk digunakan bagi para pendidik yang mencari sesuatu yang belum pernah dicoba sebelumnya yang akan dirasakan oleh para peserta didiknya dimana diajak untuk menggunakan teknologi media sosial khususnya instagram sebagai dari usaha untuk mengenalkan para peserta didik menggunakan teknologi.

\section{Metode}

Metode penelitian ini menggunakan metode penelitian kualitaitif berdasarkan dengan pengertian dari metode penelitian kualitiafi menurut Sugiyono (2014) "bahwa metode ini di sebut sebagai metode artistik, karena proses penelitiannya lebih bersifat seni (kurang berpola), dan disebut sebagai metode interpretive karena data hasil penelitian lebih berkenaan dengan interprestasi terhadap data yang ditemukan di lapangan". (Sugiyono, 2014). Metode penelitian sebagai dari landasan untuk dapatkan hasil dari cara meneliti sesuatu hal. penelitiaan ini yang peneliti pakai yaitu penelitian deskriptif kualitatif sebagai dari memperoleh hasil. Dalam hal ini Sugiyono (2014) menjekaskan pengertian tentang metode penelitian kualitatif bahwa. "Metode penelitian kualitatif dapat diartikan sebagai metode penelitian yang berlandaskan pada filsafat postpositivisme, digunakan untuk meneliti pada kondisi objek yang alamiah, (sebagai lawannya adalah experiment) dimana peneliti sebagai instrument kunci, teknik pengumpulan data dilakukan secara triangulasi (gabungan), analisis data bersifat induktif/kualitatif, dan hasil penelitian kualitatif lebih menekankan makna dari pada generalisasi" (Sugiyono, 2014).

Metode penelitian kualitatif merupakan sebuah cara untuk digunakan dalam meneliti objek yang secara alami. Kebalikan dari cara experiment yang dimana dalam hal ini peneliti merupakan sebagai sebuah instrument kunci. Dalam hal tersebut peneliti menggunakan metode penelitian deskriptif kualitatif untuk dapat melihat gambaran dari penggunaan metode poster in instagram (postingan terbaik) dalam mata pelajaran PPKn dengan materi Nilai-nilai Pancasila pada siswa kelas X-IPA 5 SMA Negeri 1 Klari. Subjek dari penelitian ialah siswa SMA Negeri 1 Klari. Sekolahan ini terdiri dari, kelas X, XI, XII dan untuk jurusannya itu ada tiga jurusan yaitu IPA, IPS, dan BAHASA. Peneliti memfokuskan penelitiannya, dikelas X-IPA 5 sebagai subjek utama dalam pengambilan data penelitian. Selain dari para siswa maka disini peneliti menarik guru, namun yang akan menjadi subjeknya itu ialah guru kelas X-IPA 5 yang mengampu mata pelajaran PPKn SMA Negeri 1 Klari.

Penelitian ini melibatakan guru dan siswa sebagai subjek utama dalam penelitian. Pelaksanaan penelitian ini untuk dapat mengetahui tentang penggunaan metode poster in instagram (postingan terbaik) dalam mata pelajaran PPKn untuk membangun karakter kreatif dan tanggung jawab di era revolusi industri 4.0. Penentuan subjek penelitian dilakukan dengan menggunakan teknik purposivesampling yang dimaksudkan untuk memperoleh data yang lebih fokus dan terarah dari setiap subjek yang relevan. Penggunaan teknik ini dalam menentukan subjek penelitian dilaksanakan dengan mengidentifikasi seseorang dalam memiliki kriteria sebagai narasumber utama. Selain itu juga ditentukan narasumber dari guru PPKn, dan beberapa siswa kelas XIPA 5. 


\section{Hasil dan Pembahasan}

Dalam hal ini pada satuan pendidikan di SMA Negeri 1 Klari yaitu memberlakukan pembelajaran jarak jauh dengan menggunakan sarana daring/online yaitu web atau aplikasi google classroom sebagai bentuk untuk mendukung kegiatan proses pembelajaran yang di laksanakan dengan jarak jauh. Aktivitas siswa untuk proses pembelajaran di SMA Negeri 1 Klari di laksanakan dirumah masingmasing. Sesuai dengan Surat edaran menteri pendidikan dan kebudayaan (mendikbud) Nomber 4 tahun 2020, proses kegiatan belajar dari rumah. Sekolah menengah atas (SMA) Negeri 1 Klari melakukan proses pembelajaran jarak jauh daring dengan menggunakan aplikasi google classroom. SMA Negeri 1 Klari merupakan sekolah yang memiliki fasilitas teknologi, seperti leb komputer, wifi, proyektor, dan bahkan untuk absen guru dengan menggunakan fingerprint. Selain dari fasilitas itu semua SMA Negeri 1 Klari juga membekali tenaga pendidiknya dengan pengetahuan tentang teknologi terkait dengan adanya wabah yang sebagai dari untuk berjalannya proses pembelajaran daring.

Saat ini dunia pendidikan sedang terdampak wabah Covid-19 yang mengharuskan proses pembelajaran diganti dengan daring/online, hal ini juga berhubungan dengan perkembangan teknologi di era revolusi industri 4.0 yang menunjukan bahwa perkembangan teknologi sejatinya akan terus berkembang dengan peningkatan-peningkatan kinerja untuk memberikan kemudahan dalam aktivitas kegiatan manusia sehari-hari. Manfaat teknologi diperlukan untuk kegiatan proses pembelajaran tetap berlangsung karena adanya wabah nonalam yang terjadi di dunia. Perkembangan teknologi saat ini menjadi sebuah potensi dalam dunia pendidikan. Teknologi bagi dunia pendidikan saat ini menjadi sarana yang dapat dipakai oleh siswa dan guru untuk keberlangsungan proses pembelajaran. Husaini (2014) dalam hal ini menjelaskan keberadaan teknologi bagi dunia pendidikan merupakan sarana yang dapat dipakai sebagai media penyampaian program pembelajaran baik secara searah maupun secara interaktif (dalam Fitriani, 2020).

Sesuai dengan Almeida \& Simoes, (2019) penggunaan teknologi telah memungkinkan munculnya pembelajaran jarak jauh dan mendorong inovasi yang lebih besar dalam menciptakan metode pengajaran di dalam dan di luar kelas (dalam Fitriani, 2020). Teknologi dalam dunia pendidikan dijadikan sebagai media pembelajaran yang efektif dan efesien. Selama kegiatan Aktivitas pembelajaran tidak memberikan kesulitan terhadap peserta didik, dalam proses pembelajaran. Pemebelajaran jarak jauh (PJJ) di SMA Negeri 1 Klari hal ini di jelaskan mengenai PPJ daring dalam laman website SMA Negeri 1 Klari yaitu dengan adanya wabah pandemi Covid-19. "Pembelajaran Jarak Jauh (PJJ) dilakukan bukan karena mau tapi karena terpaksa. Dari pada tidak belajar sama sekali, maka mencoba berbagai macam cara. Walaupun tidak optimal tetapi PJJ adalah pilihan dan kita tidak tahu PJJ sampai kapan. Apabila di kemudian hari terjadi lagi maka kita dapat melakukan PJJ" (Laman website SMA Neger 1 Klari, 2020).

Jumlah siswa kelas X-IPA 5 tahun 2020/2021 yaitu 36 orang, terdiri dari 6 siswa dan 30 siswi. Guru pengampu dari kelas X-IPA 5 mata pelajaran PPKn yaitu Ibu Nina Marlina. Dalam hal ini dapat terlihat dalam tabel 4.2 sebagai berikut. 
Tabel 4.3

Daftar Siswa Kelas X-IPA 5

\begin{tabular}{lll}
\hline No & Siswa kelas X-IPA 5 & Jumlah \\
\hline 1. & Siswa perempuan & 30 orang \\
2. & Siswa laki-laki & 6 orang \\
& & \\
\hline & Total & 36 orang \\
\hline & \multicolumn{2}{l}{ Sumber: TU SMA Negeri 1 Klari }
\end{tabular}

Beberapa aspek lainnya sebagai dari lapisan nilai dan keyakinan SMA Negeri 1 Klari yang terdiri dari, visi sekolah dan misi sekloah untuk dijadikan sebagai landasan dasar, tujuan, serta target kedepan untuk meningkatakan kualitas sekolah kearah yang lebih baik, hal ini terlihat dari visi misi sekolah SMA N 1 Klari yaitu.

Visi sekolah SMA Negeri 1 Klari

Visi SMA Negeri 1 Klari yaitu membentuk peserta didik berprestasi, disiplin, yang berwawasan lingkungan dengan dilandasi iman dan taqwa, sehingga mampu menjawab tantangan zaman yang senantiasa berubah.

\section{Misi sekolah SMA Negeri 1 Klari}

Untuk mencapai hasil belajar ataupun hasil prestasi siswa dalam hal ini sekolah memiliki misi yang diantaranya sebagai berikut.

1) Meningkatakan prestasi akademik lulusan,

2) Meningkatakn mutu pendidikan melalui pelayanan prima terhadap peserta didik,

3) Menumbuhkan bakat, minat, kreativitas, dan inovasi peserta didik melalui kegiatan ekstrakulikuler,

4) Menumbuhkan kesadaran hidup sehat,

5) Meningkatkan wawasan peduli lingkungan hidup dan kearifan budaya local,

6) Membentuk peserta didik yang disiplin, beriman, bertaqwa, dan berbudi luhur.

\section{Tujuan SMA Negeri 1 Klari}

Merupakan sebagai bagian dari tujuan pendidikan nasional untuk dijadikan sebagai bagian dari landasan dari sekolah, salah satunya SMA Negeri 1 Klari memiliki tujuan sebagai berikut.

1) Sebagai bagian dari tujuan pendidikan nasional adalah meningkatkan kecerdasan, pengetahuan, kepribadian, ahlak mulia, serta keterampilan untuk mandiri dan mengikuti pendidikan lebih lanjut.

2) Mengembangkan pembelajaran aktif, kreatif, efektif, inovatif dan menyenangkan.

3) Mengembangkan berbagai media. Bahan ajar setiap MP yang dapat membangkitkan semangat belajar, termasuk menggunakan."Alam Takambang" atau lingkungan sebagai sumber belajar untuk menjadikan pembelajaran lebih menarik.

4) Meningkatkan prestasi Akademik dan Non Akademik.

5) Mengembangkan sarana pembelajaran yang bebasis TIK untuk meningkatkan kegiatan pembelajaran. 
6) Memfokuskan dalam mengembangkan perpustakaan yang representatif berbasis, perpustakaan elektronik sebagai pusat dan primadona sumber belajar.

7) Terwujudnya suasana belajar.

8) Terwujudnya suasana belajar yang disiplin kondusif dan joyful.

Dalam hal ini yang menjadi sasaran dari SMA Negeri 1 Klari merupakan tenaga pendidik, suasana sekolah, pencapaian pembelajaran, dan pengembangan bahan ajar. Hal ini tertuang dalam laman web SMA Negeri 1 Klari sebagai berikut:

1) Meningkatkan mutu Pendidikan dengan meningkatkan kemampuan profesional tenaga kependidikan.

2) Terciptanya suasana sekolah yang kondusif untuk mewujudkan proses pembelajaran yang efektif dan efesien.

3) Mencapai pembelajaran yang efektif dan inovatif.

4) Mengembangkan bahan ajar untuk setiap mata pelajaran

Sumber Laman website SMA Negeri 1 Klari https://www.sman1klari.sch.id/profil

Beberapa hal tersebut diatas merupakan perolehan dari apa yang menjadi lapisan nilai dan keyakinan dari sekolah untuk di jadikan sebagai landasan dasar serta tujuan dan sasaran untuk mencapai target yang di yakini sebagai dari kegiatan sekolah mencangkup dari proses pembelajaran yang dilaksanakan di sekolah.

\section{Pembelajaran Jarak Jauh (PJ) Daring/Oline SMA N 1 Klari}

Aktivitas proses pembelajaran tahun ini berbeda dengan tahun-tahun sebelumnya namun tenaga pendidik dan peserta didik SMA Negeri 1 Klari tetap melaksanakan proses pembelajaran, melalui pembelajaran jarak jauh (PJJ). Pendidik dalam hal ini memiliki akses untuk melaksanakan pembelajaran dengan jarak jauh dengan bantuan teknologi. Dengan memanfaatkan kemampuan internet daring/online. Pendidik dan peserta didik melaksanakan kegiatannya dengan membuat ruangan kelas online. Menggunakan web atau aplikasi google classroom. Melalui kelas online yang telah dibuat oleh pendidik, peserta didik dapat mengakses google classroom masing-masing di smartphone atau laptopnya.

Dewi (2020) dalam hal ini menjelaskan tentang pembelajaran daring untuk siswa memiliki keleluasaan waktu belajar, dapat belajar kapanpun dan dimanapun. Siswa dapat berinteraksi dengan guru menggunakan beberapa aplikasi seperti classroom, video converence, telepon atau live chat, zoom maupun melalui whatsapp group (Dewi, 2020). Melalui pembelajaran dengan menggunakan teknologi sebagai akses dari proses pembelajaran dengan daring. Tidak melupakan dari tujuan pembelajaran itu sendiri sebagai proses untuk dapat memberikan ilmu, karakter atau tingkah laku kebiasaan siswa kearah positif. Hal ini di jelaskan oleh Sanjaya (2006) bahwa tujuan pembelajaran bukanlah penguasaan materi pelajaran, akan tetapi proses mengubah tingkah laku siswa sesuai dengan tujuan yang akan dicapainya. (Sanjaya, 2006).

Sekolah menengah atas (SMA) Negeri 1 Klari melakukan proses pembelajaran jarak jauh daring dengan menggunakan aplikasi google classroom. SMA Negeri 1 Klari merupakan sekolah yang memiliki fasilitas teknologi, seperti leb komputer, wifi, proyektor, dan bahkan untuk absen guru dengan menggunakan fingerprint. Selain dari fasilitas itu semua SMA Negeri 1 Klari juga membekali tenaga pendidiknya dengan pengetahuan tentang teknologi terkait dengan adanya wabah yang 
sebagai dari untuk berjalannya proses pembelajaran daring. Saat ini dunia pendidikan sedang terdampak wabah Covid-19 yang mengharuskan proses pembelajaran diganti dengan daring/online, hal ini juga berhubungan dengan perkembangan teknologi di era revolusi industri 4.0 yang menunjukan bahwa perkembangan teknologi sejatinya akan terus berkembang dengan peningkatanpeningkatan kinerja untuk memberikan kemudahan dalam aktivitas kegiatan manusia sehari-hari.

Manfaat teknologi diperlukan untuk kegiatan proses pembelajaran tetap berlangsung karena adanya wabah nonalam yang terjadi di dunia. Perkembangan teknologi saat ini menjadi sebuah potensi dalam dunia pendidikan. Teknologi bagi dunia pendidikan saat ini menjadi sarana yang dapat dipakai oleh siswa dan guru untuk keberlangsungan proses pembelajaran. Husaini (2014) dalam hal ini menjelaskan keberadaan teknologi bagi dunia pendidikan merupakan sarana yang dapat dipakai sebagai media penyampaian program pembelajaran baik secara searah maupun secara interaktif (dalam Fitriani, 2020). Sesuai dengan Almeida \& Simoes, (2019) penggunaan teknologi telah memungkinkan munculnya pembelajaran jarak jauh dan mendorong inovasi yang lebih besar dalam menciptakan metode pengajaran di dalam dan di luar kelas (dalam Fitriani, 2020). Teknologi dalam dunia pendidikan dijadikan sebagai media pembelajaran yang efektif ketika aktivitas pembelajaran tidak memberikan kesulitan dalam proses pembelajaran.

\section{Teknologi Media Sosial Sebagai Media Pembelajaran}

Dalam hal ini media pembelajaran yang memanfaatkan media sosial sudah banyak digunakan hal ini sesuai dengan Kind T. \& Evans Y yang menjelaskan tentang salah satu alternatif solusi yang bisa dikembangkan adalah pemanfaatan media sosial sebagai media pembelajaran. Media sosial dipilih karena merupakan trend yang sedang berkembang saat ini (dalam Irwandani, 2016). Berkaitan dengan penjelasan Tampubolon (2018) melalui media sosial instagram, diharapkan nilai-nilai karakter dapat ditanamkan dan dibiasakan sehingga menjadi budaya bersosialisasi di era globalisasi (Tampubolon, 2018). Metode pembelajaran poster in instagram (postingan terbaik) sangat cocok untuk digunakan bagi para pendidik yang mencari sesuatu yang belum pernah dicoba sebelumnya yang akan dirasakan oleh para peserta didiknya dimana diajak untuk menggunakan teknologi media sosial khususnya instagram sebagai dari usaha untuk mengenalkan para peserta didik menggunakan teknologi, dengan memberikan pemahaman menggunakan akun media sosial dengan keterampilan berprilaku baik dalam aktivitas di dunia maya.

Menjelaskan dalam ini Irwandani \& Juariah (2016) bahwa. "Peserta didik memerlukan media pembelajaran yang bersifat baru agar proses pembelajaran tidak monoton, salah satu alternatif solusi yang bisa dikembangkan adalah pemanfaatan media sosial sebagai media pembelajaran" (Irwandani \& Juariah, 2016). Banyak sekali manfaat yang dirasakan oleh pengguna teknologi media sosial jika dalam penggunaanya sesuai dan benar, selain banyaknya informasi yang dapat kita akses di media sosial dan juga beragam ilmu pengetahuan. Perkembangan teknologi menentukan terhadap hasil belajar siswa. Dalam hal ini S Shoimatul Ula (2013) menjelaskan bahwa. "Hal yang menjadi tujuan belajar salah satunya adalah adanya perubahan tingkah laku dalam diri ini. Perubahan yang diharapkan tentunya sebuah perubahan positif yang mampu membawa individu menuju kondisi yang lebih baik. Dalam proses pencapaian tujuannya, belajar dipengaruhi oleh berbagai hal. Hal inilah yang nantinya mampu menentukan berhasil tidaknya suatu proses belajar" (dalam Nofi, 2017 hlm 31).

Hasil belajar siswa dalam menggunakan metode ini sangat berpengaruh terhadap perkembangan karakter siswa yang menggunakan teknologi media sosial instagram serta untuk 
meningkatkan kreatifitas siswa dalam penggunaan metode Poster In Instagram (postingan terbaik) dalam mata pelajaran PPKn untuk membangun karakter di era revolusi industri 4.0.

Untuk mencapai hasil belajar yang diinginkan maka perlu sebuah proses dengan berbagai hal macam langkah-langkah yang sesuai dan berbagai teknik yang efesien, efektif, dan berkualitas. Metode pembelajaran menurut Reigeluch (2015) adalah mempelajari sebuah proses yang mudah diketahui, diaplikasikan dan diteorikan dalam membantu pencapaian hasil belajar (dalam Dewi, 2018).

\section{Teknologi Sosial Media Instagram sebagai dari Metode Pembelajaran Poster In Instagram (Postingan Terbaik)}

Mengenai hal yang menjadi landasan utama dalam menggunakan metode pembelajaran poster in instagram (postingan terbaik) yaitu merupakan media sosial instgaram itu sendiri. Instagram merupakan sebuah media sosial yang dapat bertukar informasi lewat berbagi foto melalui akun instagram.

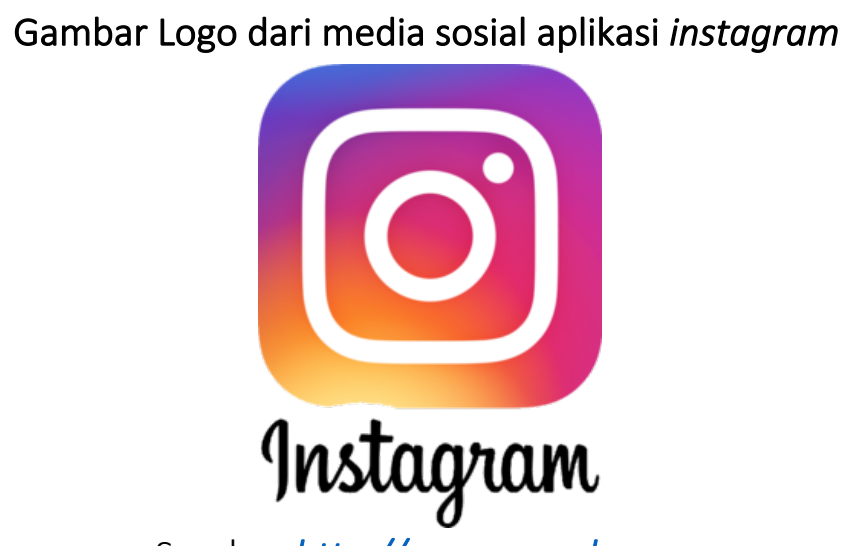

Sumber http://www.google.com

Merupakan alat atau media dari penyampaian hasil karya siswa untuk dipublikasikan. Dalam hal ini menguraikan mengenai beberapa hal yang menjadi alat atau media dari metode pembelajaran poster in instagram (postingan terbaik) tersebut.

a. Teknologi Media Sosial Instagram

Fomunyam (2019) menjelaskan mengenai Era Revolusi Industri 4.0 yang mengakibatkan semakin eratnya batas antara manusia, mesin indrustri, teknologi informasi dan komunikasi yang berdampak pada seluruh aspek kehidupan (dalam Fitriyani, 2020). Selain itu perkembangan teknologi dan informasi dalam bentuk media sosial pada saat ini sangat berdampak bagi kehidupan manusia (Tampubolon, 2018). Dalam hal ini bangsa kita ini merupakan bangsa yang besar yang menjungjung tinggi persatuan generasi hari ini. Jangan sampai kita lalai oleh perkembangan zaman namun kita harus dapat bisa bersinergi dalam menghadapi perubahan ini.

Sebagai dari semangat yang para pendahulu berikan, kita lihat dari sumpah pemuda bangsa Indonesia Nugraha \& Firmansyah menjelaskan. "Bangsa kita tercinta menjungjung tinggi persatuan bangsa tidak membedakan satu sama lain dalam ikrar sumpah pemuda pada 28 oktober 1928 melalui perwakilan bangsa, ingin disampaikan bahwa generasi Indonesia berkewajiban untuk menjaga Indonesia, melestarikan budaya, peka terhadap perubahan namun tidak meninggalkan jati diri dan nilai-nilai luhur bangsa" (Nugraha \& Firmansyah, 2018). 
Media sosial instagram sendiri adalah sebuah aplikasi sosial yang popular saat ini Ghazali (2016) menjelaskan Nama Instagram diambil dari kata insta yang asalnya instan dan gram dari kata telegram. Jadi Instagram diartikan sebagai aplikasi untuk mengirimkan informasi dengan cepat, yakni dalam bentuk foto (Ghazali, 2016). Dalam hal ini aplikasi instagram merupakan sebuah media sosial yang banyak digunakan oleh masyarakat dunia tidak terkecuali negara Indonesia. Media sosial Instagram sebagai dari, media berbagi informasi dan foto atau gambar bahkan video.

Hal ini jelas di era globalisasi dan informasi perkembangan media pembelajaran juga semakin maju, Penggunaan Teknologi Informasi sebagai media pembelajaran sudah merupakan suatu tuntutan (Muhson, 2010). Dalam menghadapi perkembangan zaman yang begitu maju banyak sekali hal-hal yang berubah dengan adanya smartphone sebagai alat komunikasi saat ini untuk dapat terus berinteraksi dengan sesama walaupun jaraknya berjauhan satu sama lain. Aktivitas ini memberikan kemudahan untuk umat manusia selain dari pada itu juga dapat kita jadikan sebagai media pembelajaran yang menarik sambil belajar menggunakan teknologi secara baik.

Muhson (2010) Media pembelajaran merupakan wahana penyalur pesan dan informasi belajar, Media pembelajaran yang dirancang secara baik akan sangat membantu peserta didik dalam mencerna dan memahami materi pelajaran (Muhson, 2010). Dalam buku "Kelas PPKn Pak Kribo" poster in instagram (postingan terbaik) adalah sebuah media pembelajaran dengan menggunakan aplikasi instagram yang memberikan informasi dan postingan gambar atau foto beserta caption atau kata-kata yang sudah dirangkai dengan sedemikian rupa (tampubolon, 2018).

Siswa diajak untuk membuat sebuah karya yang menyangkut dengan materi nilai-nilai Pancasila serta guru mengambil tema yang menyesuaikan dengan hari besar nasional yaitu hari kemerdekaan Republik Indonesia bertepatan dengan tanggal 17 Agustus. Tema yang di ambil oleh guru merupakan tema yang besar kaitannya dengan hari kemerdekaan Republik Indonesia yaitu "Menjelang 17 Agustusan Hari Kemerdekaan Republik Indonesia Yang Ke 75".

\section{b. Manfaat Media Sosial Instagram sebagai Metode Pembelajaran}

Pemilihan teknologi media sosial instagram dirasa penggunaannya mudah dan hampir setiap siswa memiliki akun instagram. Segi menjelaskan penggunaan Instagram lebih dimanfaatkan untuk mempermudah guru dalam memantau kegiatan siswa. Kreativitas siswa juga bisa diukur dari hasil karya yang diunggah ke Instagram (dalam Utami, 2015). Agustinus Tampubolon (2018) menjelskan media ini merupakan bagian dari pembelajaran untuk memanfaatkan media sosial agar menjadi sarana positif dan bijaksana bagi penikmat dan penggunanya (Tampubolon, 2018). Metode pembelajaran poster in instagram (postingan terbaik). Metode pembelajaran yang karena dirasa cocok dengan materi Nilai-nilai Pancasila dalam mata pelajaran PPKn dimana metode ini merupakan metode yang mengedepankan pendidikan berbasis nilai. Akativitas pembelajaran metode poster in instagram (postingan terbaik) yaitu siswa diajak berpikir kreatif dan bertanggung jawab. Siswa dituntut untuk membuat sebuah karya foto atau video yang nantinya diposting di akun Instagram.

Melalui metode pembelajaran poster in instagram (postingan terbaik) guru melakukan proses pembelajaran dengan memberikan pemahaman siswa untuk tugas diskusi dalam memproleh karya. Materi nilia-nilai Pancasila dan disesuaikan dengan hari nasional Indonesia, guru memberikan tugas untuk dilaksanakan oleh siswa dengan harapan dapat membangun karakter kreatif dan tanggung jawab. Guru mengajak siswa untuk dapat berpikir keratif dalam menuangkan sebuah ide pada proses pembelajaran. Siswa melaksanakan apa yang telah diintruksikan oleh guru yang sebagaimana dalam intruksinya itu sebagai berikut: 
1) Posting gambar, foto atau video yang bertemakan "Menjelang 17 Agustus, Hari Kemerdekaan Indonesia Yang Ke 75" dengan hasil karya sendiri atau jika menggunakan karya orang lain sertakan sumbernya.

2) Gunakan caption atau kata-kata yang bertemakan "Menjelang 17 Agustus, Hari Kemerdekaan Indonesia Yang Ke 75" dengan hasil karya sendiri atau dengan karya orang lain sertakan sumbernya.

3) Tidak boleh menggunakan postingan yang dengan hal-hal negatif seperti propokasi, mengkritisi berlebihan, pencemaran nama baik, dan hal yang dilarang lainnya oleh pemerintah.

Setelah mendapatkan hasil terbaik yang diperoleh maka siswa diajak untuk memposting hasilnya itu di instagram miliknya, dengan melalui hasil yang dipostinya itu disertkan hastag (\#) untuk memudahakan dalam mencari dan dunia dapat melihat dengan mudah dari hastag tersebut. Hasteg dalam tema ini merpakan "Hut RI ke 75".

\section{Simpulan}

Berdasarkan hasil yang dilaksanakan pada penelitian ini, dalam proses pembelajaran dengan menggunakan metode pembelajaran poster in instagram (postingan terbaik). Guru dan siswa memeriahkan hari besar nasional Indonesia melalui media sosial instagram, walau hari besar nasional masih beberapa hari lagi namun antusias-antusias sudah terasa dengan memerihakan, menginformasikan, dan mempersiapkan di akun media sosial instagram. Sekaligus untuk mengajak pemabaca dapat ikut antusias dalam menjelang hari kemerdekaan Revublik Indonesia yang ke 75.

Kegiatan yang sudah menjadi kebiasaan dari sejak lama seperti memasang bendera sangsaka merah putih di halaman depan rumah, mempersiapkan acara-acara yang akan dilaksanakan pada tanggal 17 agustus, dan gotong royong untuk membersihkan lingkungan atau pun mengecat ulang pagar atau gapura atau yang lainnya. Dengan karena adanya media sosial dimudahkan untuk dapat mengbagikan kegiatan tersebut dan untuk saling mengingatkan sekaligus mengajak masyarakat lain untuk dapat memberikan motivasi dalam partisipasi memeriahkan hari raya kemerdekaan.

Tema yang diambil dalam kegiatan pembelajaran pada mata pelajaran PPKn materi nilai-nilai Pancasila. Dalam hal ini guru menyesuaikan, dengan mendapatkan kesempatan yang tepat. Dalam hal ini tema yang diambil yaitu menjelang hari kemerdekaan Indonesia yang ke 75. Siswa diajak untuk memposting hal-hal yang berhubungan dengan perayaan aktivitas kegiatan kemerdekaan Indonesia sebelum hari kemerdekaan itu tiba. Siswa memanfaatkan media sosial, mengajak untuk melakukan aktivitas positif dalam menggunakan akun media sosialnya. Kegiatan pembelajaran dilaksanakan dengan siswa memposting kegiatan mereka di lingkungannya masing-masing berupa foto, gambar, atau video berdurasi pendek. Memberikan semangat kemerdekaan dalam sebuah kalimat yang di tuangkan di postingannya tersebut, mengajak pembaca, memotivasi, dan tentunya memberikan informasi yang baik.

\section{Referensi}

Alfa, A. (2018). Industri Konstruksi di Era Industri 4.0. Soledang Mayang, vol. 4, no. 3, 168-169. Diakses tanggal $02 \quad$ April 2020 dari: https://ojs.selodangmayang.com/index.php/bappeda/article/view/107 
Dewi, Wahyu A.F. (2020) Dampak Covid-19 Terhadap Implementasi Pembelajaran Daring Di Sekolah Dasar. EDUKATIF: Jurnal IImu Pendidikan. Vol. 2, No. 1. Hal. 55-61. Diakses 10 Agustus 2020 dari: https://www.edukatif.org/index.php/edukatif/article/view/89/pdf

Fitriyani, Y., Fauzi I., \& Sari M. Z. (2020). Motivasi Belajar Mahasiswa Pada Pembelajaran Daring Selama Pandemik Covid-19. Jurnal kependidikan. Vol. 6, no 2. Hal. 165-175. Diakses 02 Agustus 2020

dari: http://jurnal.ikipmataram.ac.id/index.php/jurnalkependidikan/article/view/2654

Ghazali, M. (2016). Buat Duit Dengan Facebook dan Instagram: Panduan Menjana Pendapatan dengan Facebook dan Instagram, Malaysia: Publishing House. Hal. 8. Diakses pada tanggal 31 Agustus 2020 dari: https://pts.com.my/buku/buat-duit-dengan-facebook-dan-instagram

Ibda, H. (2018). Penguatan Literasi Baru Pada Guru Madrasah Ibtidaiyah dalam Menjawab Tantangan Era Revolusi Industri 4.0. JRTIE. Journal of Research and Thought of Islamic Education, vol 1, No 2. Diakses tanggal 20 Maret 2020 dari: http://jurnaliainpontianak.or.id/index.php/jrtie/article/view/1064

Irwandani \& Juariah, S. (2016). Pengembangan Media Pembelajaran Berupa Komik Fisika Berbantuan Sosial Media Instagram Sebagai Alternatif Pembelajaran. Jurnal IImiah Pendidikan Fisika Al-BiRuNi, vol. 5, no. 1, hal 34-42. Diakses tanggal 08 April 2020 dari: http://103.88.229.8/index.php/al-biruni/article/view/103

Muhson, A. (2010). Pengembangan Media Pembelajaran Berbasis Teknologi Informasi. Jurnal Pendidikan Akuntansi Indonesia, 8, 1-2. Diakses tanggal 08 April 2020 dari: https://journal.uny.ac.id/index.php/jpakun/article/view/94

Nugraha, Y. \& Rahmatiani, L. (2017). Pelaksanaan dan Peran Kegiatan Ekstrakurikuler dalam Pembinaan Karakter Disiplin Siswa. Prosiding Konferensi Nasional Kewarganegaraan III, 9697. Diakses tanggal 21 Maret 2020 dari: http://eprints.uad.ac.id/9765/

Sanjaya, W. (2006). Strategi Pembelajaran Berorientasi Standar Proses Pendidikan. Jakarta: Kencana Prenadamedia Group.

Sugiyono, (2014). Metode Penelitian Kuantitatif Kualitatif dan R\&D. Bandung: Alfabeta.

Tampubolon, A. (2018). Kelas PPKn Pak Kribo. Surabaya: Pustaka Media Guru.

Utami, R. P. Probosari, R. M. \& Fatmawati, U. (2015). Pengaruh Model Pembelajaran Project Based Learning Berbantu Instagram Terhadap Kemampuan Berpikir Kreatif Siswa Kelas X Sma Negeri 8 Surakarta. BIO-PEDAGOGI, Jurnal Pembelajaran Biologi, vol 4. No 1, 47-52. Diakses tanggal 02 Agustus 2020 dari: https://jurnal.uns.ac.id/pdg/article/view/5364/4762 